\title{
Detection of moderate protein-energy malnutrition in pre-school children
}

\author{
F. Delpeúch, A. Cornu and P. Chevalier \\ Onarest Nutrition Unit, Yaounde, P.O. Box 193, Cameroon
}

\begin{abstract}
Summary
Several biochemical and anthropometric tests were used to define the states of mild or moderate protein-energy malnutrition among 810 children aged under five years in the forest region of Southern Cameroon. The results show that the percentage and the identity of children classified as undernourished may be different according to the anthropometric test employed. The mean values of most of the biochemical variables assayed decrease in the groups affected with moderate weight and arm deficiencies. A system is proposed for the evaluation of the nutritional status based on the simultaneous use of four anthropometric tests. Some biochemical parameters may be useful for establishing a diagnosis.
\end{abstract}

\section{Introduction}

Previous research (JELLIFFE, 1966) has shown that children up to five years of age constitute the highest risk group for protein-energy malnutrition. Moreover, without wishing to underestimate the value of clinical cases, most cases of malnutrition observed in Africa are mild or moderate in form and are therefore difficult to screen. The recognition of these forms is very important from a public health standpoint.

In order to define the states of protein-energy malnutrition various authors have proposed some simple anthropometric criteria such as weight for age (GOMEZ et al., 1956), weight for height (WATERLOW, 1972), arm circumference for age (JELLIFFE \& JELLIFFE, 1969) and ratio arm circumference/head circumference (KANAWATI \& MACLAREN, 1970). While it would be expected that these various measurements would yield the same data, recent publications by JEANNEE et al. (1976) and VIJAYARAGHAVAN \& GOWRINATH-SASTRY (1976) have shown that children classified as malnourished according to one test could be classified as normal according to another, especially in cases of moderate deficiencies. It thus seems that detection based on a single anthropometric test could lead to false or incomplete results and that more satisfactory results would be obtained if a battery of tests was used. For this reason, we have chosen four anthropometric tests and seven biochemical variables in which levels decrease in severe forms of proteinenergy malnutrition as shown by several workers (WHITEHEAD, 1965; INGENBLEEK et al., 1972; SMITH et al., 1973; NEUMANN et al., 1975; REEDS \& LADITAN, 1976).

In the present work, we have attempted to define the possibilities of simultaneous utilization of several anthropometric fests as well as the possibility

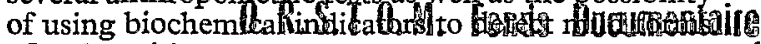
of malnutrition.

\section{Subjects and Material}

The study involved 810 children from the forest region of Southern Cameroon, whose staple diet consists primarily of cassava, plantain and various tubers. Sampling was performed in such a way as to assure the representation of all age groups up to five years. Birthdays were taken from birth certificates. With the exception of a typical case of marasmus secondary to measles, no case of severe malnutrition was observed.

The following four anthropometric criteria were chosen: weight for age, weight for height, arm circumference for age and the ratio of arm/head circumferences. All the measurements were performed according to standard procedures described by JeLLIFFE (1966). The results are expressed as percentage of Harvard standards expected (STUART \& STEVENSON, 1959) for weight criteria and Wolanski's standards (JELLIFFE, 1966) for arm circumference for age. For each of these criteria the children were classified as shown in Table $I$. Finally, we determined for each criterion a threshold beneath which a state of moderate malnutrition could be suspected. The levels of these thresholds were chosen among all those corresponding to moderate anthropometric deficiencies so as to obtain a maximum of agreement between all criteria when paired. It should be recalled that a level of agreement is defined as the percentage of children who are simultaneously classified by two criteria in the categories "well to do healthy children" or "malnourished" according to the thresholds tested. Thus, the greater the agreement between two criteria, the more precise is the definition of a state of undernutrition according to these criteria. The thresholds are the following: weight for age, $80 \%$, of the standard; weight for height, $90 \%$; arm circumference for age, $85 \%$, and ratio of arm/head circumferences, $0 \cdot 290$. The significance of these thresholds will be discussed in relation to the biochemical tests. A classification of the children is proposed, based on considerations of the four criteria and the thresholds chosen (Table II): Group 0-children whose four criteria are greater than the thresholds; Groups 1, 2, 3, 4children having one, two, three and four criteria which are lower than the thresholds.

Blood was taken by venous puncture in the femoral vein, using the system of "vacutainer" tubes. Urine was collected once in the morning. After coagulation and centrifugation of blood, the serum obtained as well as urine were stored at $-18^{\circ} \mathrm{C}$ before the analysis. The following variables were assayed: total protein hay ethe method of GORNALI (1949); electrophoretic fractions of serum 
Table I-Biochemical data of children classified according to several anthropometric tests (a)

\begin{tabular}{|c|c|c|c|c|c|c|c|c|c|}
\hline & & $\begin{array}{l}\text { No. of } \\
\text { children }\end{array}$ & $\begin{array}{c}\text { Total } \\
\text { protein } \\
\mathrm{g} / 100 \mathrm{ml}\end{array}$ & $\begin{array}{l}\text { Albumin } \\
\mathrm{g} / 100 \mathrm{ml}\end{array}$ & $\frac{\text { Albumin }}{\text { Globulins }}$ & $\begin{array}{l}\text { Prealbumin } \\
\mathrm{mg} / 100 \mathrm{ml}\end{array}$ & $\begin{array}{l}\text { Transferrin } \\
\mathrm{mg} / 100 \mathrm{mI}\end{array}$ & $\begin{array}{l}\text { Complement } \\
\text { C3 } \\
\mathrm{mg} / 100 \mathrm{ml}\end{array}$ & $\begin{array}{l}\text { Hydroxy- } \\
\text { proline } \\
\text { index }\end{array}$ \\
\hline $\begin{array}{l}\text { Percentage } \\
\text { expected } \\
\text { weight } \\
\text { for age }\end{array}$ & $\begin{array}{l}>91 \\
90-81 \\
80-71 \\
70-61 \\
\leqslant 60\end{array}$ & $\begin{array}{r}400 \\
264 \\
113 \\
24 \\
9\end{array}$ & $\begin{array}{ll}6 \cdot 92 \pm 0 \cdot 04^{\mathrm{c}} \\
6 \cdot 96 \quad 0 \cdot 05^{\mathrm{c}} \\
7 \cdot 04 & 0 \cdot 07^{\mathrm{c}} \\
6 \cdot 87 & 0 \cdot 13^{\mathrm{b}} \\
6 \cdot 24 & 0.27^{\mathrm{b}}\end{array}$ & $\begin{array}{ll}3 \cdot 71 \pm 0.02^{\mathrm{c}} \\
3 \cdot 67 & 0.03^{\mathrm{c}} \\
3 \cdot 64 & 0.03^{\mathrm{c}} \\
3.52 & 0.08^{\mathrm{b}} \\
3 \cdot 12 & 0.19^{\mathrm{b}}\end{array}$ & $\begin{array}{ll}1 \cdot 21 \pm 0.01^{\mathrm{c}} \\
1 \cdot 13 & 0.01^{\mathrm{d}} \\
1.09 & 0.02^{\mathrm{d}} \\
1.07 & 0.03^{\mathrm{b}} \\
1.02 & 0.07^{\mathrm{b}}\end{array}$ & $\begin{array}{rr}12 \cdot 9 \pm 0 \cdot 2^{\mathrm{c}} \\
12 \cdot 3 & 0 \cdot 3^{\mathrm{c}} \\
12 \cdot 3 & 0 \cdot 3^{\mathrm{c}} \\
10 \cdot 7 & 0 \cdot 6^{\mathrm{b}} \\
9 \cdot 9 & 1 \cdot 5^{\mathrm{b}}\end{array}$ & 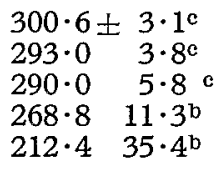 & $\begin{array}{ll}86 \cdot 6 \pm & 0 \cdot 8^{c} \\
84 \cdot 3 & 1 \cdot 0^{c} \\
84 \cdot 6 & 1 \cdot 9^{c} \\
77 \cdot 5 & 3 \cdot 3^{b} \\
63 \cdot 5 & 3 \cdot 3^{b}\end{array}$ & $\begin{array}{ll}3 \cdot 5 \pm 0 \cdot 1^{c} \\
3 \cdot 0 & 0 \cdot 1^{d} \\
2 \cdot 8 & 0 \cdot 1^{d} \\
2 \cdot 1 & 0 \cdot 2^{b} \\
2 \cdot 1 & 0 \cdot 3^{b}\end{array}$ \\
\hline $\begin{array}{l}\text { Percentage } \\
\text { expected } \\
\text { weight } \\
\text { for height }\end{array}$ & $\begin{array}{l}>91 \\
90-81 \\
80-71 \\
\leqslant 70\end{array}$ & $\begin{array}{r}641 \\
149 \\
16 \\
4\end{array}$ & $\begin{array}{ll}6 \cdot 89 \pm 0 \cdot 03^{\mathrm{c}} \\
7 \cdot 10 & 0 \cdot 04^{\mathrm{d}} \\
6 \cdot 46 & 0 \cdot 12^{\mathrm{b}} \\
6 \cdot 35 & 0 \cdot 54^{\mathrm{b}}\end{array}$ & $\begin{array}{ll}3 \cdot 67 \pm 0 \cdot 02^{\mathrm{c}} \\
3 \cdot 70 & 0 \cdot 04^{\mathrm{c}} \\
3 \cdot 46 & 0 \cdot 10^{\mathrm{b}} \\
3 \cdot 22 & 0 \cdot 39^{\mathrm{b}}\end{array}$ & $\begin{array}{ll}1 \cdot 17 \pm 0 \cdot 01^{\mathrm{c}} \\
1 \cdot 12 & 0 \cdot 02^{\mathrm{d}} \\
1 \cdot 18 & 0 \cdot 15^{\mathrm{b}} \\
1 \cdot 04 & 0 \cdot 13^{\mathrm{b}}\end{array}$ & $\begin{array}{rr}12 \cdot 7 \pm 0 \cdot 1^{c} \\
12 \cdot 2 & 0 \cdot 3^{c} \\
10 \cdot 8 & 0 \cdot 9^{b} \\
9 \cdot 5 & 2 \cdot 9^{b}\end{array}$ & $\begin{array}{lr}297 \cdot 3 \pm 2 \cdot 5^{\mathrm{c}} \\
284 \cdot 2 & 5 \cdot 0^{\mathrm{d}} \\
268 \cdot 8 & 15 \cdot 1^{\mathrm{b}} \\
227 \cdot 5 & 57 \cdot 1^{\mathrm{b}}\end{array}$ & $\begin{array}{lr}85 \cdot 6 \pm & 0 \cdot 7^{c} \\
83 \cdot 5 & 1 \cdot 4^{c} \\
78 \cdot 2 & 5 \cdot 3^{b} \\
68 \cdot 8 & 12 \cdot 9^{b}\end{array}$ & $\begin{array}{ll}3 \cdot 3 \pm 0 \cdot 1^{\mathrm{c}} \\
2 \cdot 7^{0} & 0 \cdot 1^{\mathrm{d}} \\
2 \cdot 2 & 0 \cdot 3^{\mathrm{b}} \\
2 \cdot 4 & 0 \cdot 3^{\mathrm{b}}\end{array}$ \\
\hline $\begin{array}{l}\text { Percentage } \\
\text { expected } \\
\text { arm circ. } \\
\text { for age }\end{array}$ & $\begin{array}{l}>86 \\
85-81 \\
80-71 \\
\leqslant 70\end{array}$ & $\begin{array}{r}610 \\
133 \\
62 \\
5\end{array}$ & $\begin{array}{ll}6 \cdot 94 \pm 0 \cdot 03^{\mathrm{c}} \\
6 \cdot 89 & 0 \cdot 07^{\mathrm{c}} \\
6 \cdot 97 & 0 \cdot 10^{\mathrm{c}} \\
6 \cdot 83 & 0 \cdot 19^{\mathrm{b}}\end{array}$ & $\begin{array}{ll}3 \cdot 71 \pm 0.02^{\mathrm{c}} \\
3.59 & 0.04^{\mathrm{d}} \\
3.53 & 0.05^{\mathrm{d}} \\
2.91 & 0.22^{\mathrm{b}}\end{array}$ & $\begin{array}{ll}1 \cdot 18 \pm 0 \cdot 01^{\mathrm{c}} \\
1 \cdot 10 & 0 \cdot 02^{\mathrm{de}} \\
1 \cdot 10 & 0 \cdot 05^{\mathrm{ce}} \\
1 \cdot 01 & 0 \cdot 10^{\mathrm{b}}\end{array}$ & $\begin{array}{rr}12 \cdot 9 & -0 \cdot 1^{\mathrm{c}} \\
11 \cdot 9 & 0 \cdot 3^{\mathrm{d}} \\
10 \cdot 8 & 0 \cdot 4^{\mathrm{e}} \\
8 \cdot 2 & 0 \cdot 9^{\mathrm{b}}\end{array}$ & $\begin{array}{lr}299 \cdot 6 \pm 2 \cdot 5^{\mathrm{c}} \\
284 \cdot 0 & 5 \cdot 4^{\mathrm{d}} \\
274 \cdot 3 & 7 \cdot 6^{\mathrm{d}} \\
184 \cdot 4 & 49 \cdot 3^{\mathrm{b}}\end{array}$ & $\begin{array}{lr}86 \cdot 5 \pm & 0 \cdot 7^{\mathrm{c}} \\
82 \cdot 4 & 1 \cdot 4^{\mathrm{d}} \\
77 \cdot 4 & 2 \cdot 6^{\mathrm{d}} \\
50 \cdot 4 & 11 \cdot 4^{\mathrm{b}}\end{array}$ & $\begin{array}{ll}3 \cdot 4 & \pm 0 \cdot 1^{\mathrm{c}} \\
2 \cdot 7 & 0 \cdot 1^{\mathrm{d}} \\
2 \cdot 6 & 0 \cdot 2^{\mathrm{d}} \\
2 \cdot 2 & 0 \cdot 5^{\mathrm{b}}\end{array}$ \\
\hline $\begin{array}{l}\text { ratio } \\
\text { arm circ./ } \\
\text { head circ. }\end{array}$ & $\begin{array}{r}>0 \cdot 311 \\
0 \cdot 310-0 \cdot 291 \\
0 \cdot 290-0 \cdot 271 \\
\leqslant 0 \cdot 270\end{array}$ & $\begin{array}{r}357 \\
246 \\
153 \\
54\end{array}$ & $\begin{array}{ll}6 \cdot 99 \pm 0.04^{\mathrm{c}} \\
6 \cdot 93 \quad 0 \cdot 05^{\mathrm{ce}} \\
6 \cdot 77 & 0.06^{\mathrm{de}} \\
6.73 & 0.12^{\mathrm{de}}\end{array}$ & $\begin{array}{ll}3.76 \pm 0.02^{\mathrm{c}} \\
3.67 & 0.03^{\mathrm{c}} \\
3.51 & 0.04^{\mathrm{d}} \\
3.48 & 0.06^{\mathrm{d}}\end{array}$ & 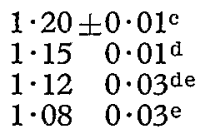 & $\begin{array}{ll}13 \cdot 1 \pm 0 \cdot 2^{\mathrm{c}} \\
12 \cdot 4 & 0 \cdot 2^{\mathrm{d}} \\
12 \cdot 0 & 0 \cdot 3^{\mathrm{d}} \\
10 \cdot 7 & 0 \cdot 4^{\mathrm{e}}\end{array}$ & $\begin{array}{lr}301 \cdot 5 \pm & 3 \cdot 2^{\mathrm{c}} \\
300 \cdot 0 & 3 \cdot 9^{\mathrm{c}} \\
274 \cdot 9 & 4 \cdot 7^{\mathrm{d}} \\
259 \cdot 0 & 10 \cdot 0^{\mathrm{d}}\end{array}$ & $\begin{array}{ll}88 \cdot 6 \pm & 0 \cdot 9^{c} \\
85 \cdot 8 & 0 \cdot 8^{d} \\
79 \cdot 5 & 1 \cdot 3^{e} \\
77 \cdot 5 & 2 \cdot 9^{e}\end{array}$ & $\begin{array}{ll}3 \cdot 5 \pm 0 \cdot 1^{c} \\
3 \cdot 1 & 0 \cdot 1^{d} \\
2 \cdot 6 & 0 \cdot 1^{e} \\
2 \cdot 8 & 0 \cdot 2^{e}\end{array}$ \\
\hline
\end{tabular}

(a) values given mean \pm s.e.m.

(b) number of children too small for valuable statistical comparisons.

(c, d, e) for each anthropometric and biochemical test, values with no common superscript are significantly different from one another $(\mathrm{P}<0 \cdot 05)$. 
protein on strips of acetate cellulose stained with Ponceau red; prealbumin, transferrin and the third component of complement by radial immunodiffusion on plates and with "Behringwerke" control serum; urine hydroxyproline index as described by WhITEHEAD (1967). Comparisons of means were performed with Student's ' $\mathrm{t}$ ' test. Significance is given for $\mathrm{P}<0.05$.

\section{Results}

Table I includes all the biochemical results from children classified according to the various anthropometric tests.

Classification according to weight for age: only the albumin/globulins ratio and the hydroxyproline index show a significant decrease for the group having a weight less than $90 \%$ expected. The decreases observed in the group less than $70 \%$ could not be statistically interpreted because of the small number of individuals.

Classification according to weight for height: a significant decrease is observed for albumin/ globulins ratio, transferrin and hydroxyproline index, beginning with the $90 \%$ threshold. The number of individuals below $80 \%$ is too small to enable us to reach any conclusion about the significance of the decreases.

Classification according to arm circumference for age: all the parameters assayed except total protein have mean values which are significantly reduced in the group of children whose arm circumference is lower than $85 \%$ expected.

Classification according to the ratio of arm/head circumferences: the albumin/globulins ratio, prealbumin, complement $\mathrm{C} 3$, and hydroxyproline index all have mean values which are signficantly lower in the group below $0 \cdot 310$. The other variables decrease below $0 \cdot 290$.

Table II indicates the means values of the anthropometric and biochemical parameters of the children classified according to the number of anthropometric criteria lower than the thresholds chosen. Group 0 may thus be considered a group of control children. The only significant differences observed between Groups 0 and 1 involve transferrin and hydroxyproline index. With the exception of total protein, all the biochemical parameters of Groups 2, 3 and 4 have values which are significantly different from those of Group 0. The decrease appears to be continuous from Group 0 to Group 4 for most of the variables.

\section{Discussion}

The first result of our study is to show that there is a decrease of the mean level of several serum and urine variables in those groups of children exhibiting moderate weight and arm deficiencies. It should be noted that the significant decreases of the biochemical parameters most often agree well with the thresholds determined by agreement calculations. Thus, at the threshold of $85^{\circ}$, for arm circumference for age and 0.290 for the ratio of arm/head circumference, all the biochemical variables except total protein have mean values which are significantly depressed. The lower sensitivity of total proteins may be explained by an increase of gamma-globulins 
which compensates the decrease of the other protein fractions. The weight thresholds seem to be less satisfactorily verified since only some parameters (transferrin, albumin/globulins and hydroxyproline index) exhibit decreased values beneath these thresholds. In our population, the weight criteria, which incidentally are often taken as a reference, thus seem less sensitive than the arm tests for defining states of moderate malnutrition. This does not, however, mean that they should be abandoned, since in certain cases they are capable of detecting undernourished children who would otherwise be classified as "well to do healthy" by arm tests only.

The second finding of our study is to show the importance of employing several tests for estimating a prevalence of malnutrition in a population, as well as for detecting individual cases. Concerning the estimation of a prevalence, the numbers of children for each class (Table I) show that, for the thresholds chosen and in spite of the maximum level of agreement, the percentages of children classified as undernourished are somewhat different as a function of the criterion: $18 \%$ for weight for age, $21 \%$ for weight for height and $25 \%$ for the arm tests. Concerning screening for malnutrition cases, examination of the individual data shows that children classified as undernourished by one test are not always so by another, For moderate deficiencies the maximum levels of agreement vary between $75 \%$ (weight for age and ratio of arm/head circumference) and 90\% (arm circumference for age and ratio of arm/head circumferences). Thus, up to $25 \%$ of the children can be classified differently by two tests. We offer here a confirmation of previous researches (JEANNEE et al., 1976; VIJAYARAGHAYAN \& GOWRINATH SASTRI, 1976) which showed that the various anthropometric tests are not necessarily interchangeable. For this reason we propose more fully to define the state of proteinenergy malnutrition in children by simultaneously utilizing four criteria (Table II). Thus, 482 and 53 children from the 810 are classed as "well to do healthy" and undernourished respectively by all four criteria. The mean values of all the biochemical parameters, except the total protein, are significantly lower in Groups 2, 3 and 4 than in Group 0 . It appears that Group 2 may be considered as the stage at which malnutrition is really effective in spite of the moderation of anthropometric deficiencies observed. Group 1, on the other hand (children presenting only one deficient criterion), has only two parameters, transferrin and hydroxyproline index, whose mean values are lower than those of Group 0. Group 1 could be considered a group of children at the limit of malnutrition and who should be monitored.

Our system, based only on anthropometric measurements, seems satisfactory for evaluating the prevalence of malnutrition. To the extent that the children of Group 1 may be considered as suffering from mild malnutrition, prevalence is $40 \%$ in our sample of population. If indications concerning the degree of malnutrition are desired, all that is necessary is to consult the real values of the deficiencies of each test. If the nutritional state at the level of the individual is to be established with precision, several biochemical assays should be included whenever possible. The importance of inter-individual variations of the biochemical values in a group of children leads us to recommend a diagnosis based on several parameters. The hydroxyproline index, which is very sensitive and which requires only a urine sample, appears to us to be a highly valuable diagnostic tool. However, recent work by WENLOCK (1977) has shown that malaria could depress this index. This fact must be taken into account when considering the significance of the index in malarial areas. Prealbumin and transferrin, assayed with $5 \mathrm{ml}$ of serum (blood taken by a simple finger puncture), have a great interest. For the population studied, transferrin seems to be a more sensitive indicator than prealbumin. They indicate together an alteration of the liver function which leads to depressed synthesis. It should be also recalled that transferrin concentrations are modified in cases of severe anaemia (INGENBLEEK et al., 1975).

Finally we would insist on the fact that our study has been carried out in Southern Cameroon where the staple is plantain, cassava and other tubers. On this type of diet biochemical abnormalities leading to the kwashiorkor type of protein-energy malnutrition are quite likely. This could probably account for such a good agreement between the anthropometry and the biochemistry, even for moderate deficiencies. We are now attempting to assess the effect of moderate protein-energy malnutrition on biochemical variables in Northern Cameroon where the staple is sorghum.

\section{References}

Gomez, F., Galvan, R. R., Frenk, S., Munoz, J. C., Chaves, R. \& Vasquez, J. (1956). Mortality in second and third degree malnutrition. Fournal of Tropical Pediatrics, 2, 77-83.

Gornall, A. C., Bardavill, C. J. \& David, M. M. (1949). Determination of serum protein by means of the Biuret reaction. Fournal of Biological Chemistry, 177, 751-753.

Ingenbleek, Y., De Visscher, M. \& De Mayer, Ph. (1972). Measurement of prealbumin as index of P.C.M. Lancet, ii, 106-109.

Ingenbleek, Y., Schrieck, H. G., De Nayer, Ph. \& De Visscher, M. (1975). Albumin, transferrin and the T.B.P.A.-R.B.P. complex in assessment of malnutrition. Clinica et Chimica Acta, 63, 61-67.

Jeannée, E., De Ville de Goyet, C. \& Bouckaert, A. (1976). Anthropométrie nutritionnelle et mesure de la circonférence brachiale. Afrique Medicale, 15, 625-628.

Jelliffe, D. B. (1966). The assessment of the nutritional status of the community. Geneva: W.H.O. Monograph Series, No. 53.

Jelliffe, D. B. \& Jelliffe, E. F. P. (1969). The arm circumference as a public health index of P.C.M. of early childhood. Fournal of Tropical Pediatrics, 15, 209-212.

Kanawati, A. \& Maclaren, D. S. (1970). Assessment of marginal denutrition. Nature, 228, 573-575.

Neumann, C. G., Lawlor, C. S., Stiehm, E. R., Swendseid, M. E., Newton, C., Herbert, J., Amman, A. J. \& Jacob, M. (1975). Immunologic responses in malnourished children. American fournal of Clinical Nutrition, 28, 89-104. 
Reeds, P. J. \& Laditan, A. A. O. (1976). Serum albumin and transferrin in protein-energy malnutrition. British fournal of Nutrition, 36, 255263.

Smith, F. R., Goodman, D. S., Zaklama, M. S., Gabr, M. K., El Maraghy, S. \& Patwardhan, V. N. (1973). Serum vitamin A, retinol binding protein and prealbumin concentrations in P.C.M. I. A functional defect in hepatic retinol release. American fournal of Clinical Nutrition, 26, 973981.

Stuart, H. C. \& Stevenson, S. S. (1959). Textbook of Pediatrics. W. Nelson (Editor). Philadelphia: W. B. Saunders.

Vijayaraghavan, K., \& Gowrinath Sastry, J. (1976). The efficacy of arm circumference as a substitute for weight in assessment of protein-calorie malnutrition. Annals of Human Biology, 3, 229233.

Waterlow, J. C. (1972). Classification and definition of protein-calorie malnutrition. British Medical fournal, iii, 566-569.

Wenlock, R. W. (1977). Hydroxyproline index as a tool for nutrition status surveys in malarial regions. British Fournal of Nutrition, 38, 239-243.

Whitehead, R. G. (1965). Hydroxyproline creatinine ratio as an index of nutritional status and rate growth. Lancet, ii, 567-570.

Whitehead, R. G. (1967). Biochemical tests in differential diagnosis of protein and calorie deficiencies. Archives of Diseases of Childhood, 42, 479-483.

Accepted for publication 9th April, 1979.

\section{New Fellows}

\section{Elected 13 December, 1979}

Afshar-Said, A., $M D$, Iran

Al Karmi, T. O., BSc, MSc, Canada

Al-Shammary, M. A. A., MB, ChB, Iraq

Amin, A. M., BSc, MSc, Britain

Babiker, E. A., MD, Belgium

Bachir, S. A. A., $\mathrm{MB}, \mathrm{ChB}$, Iraq

Baya, E. I., MBBS, MSc, Sudan

Bhachu, S. S., $M B, C h B$, Tanzania

Bhandari, B., $M D$, DCM, India

Bhaumik, B. C., MBBS, India

Brooks, B. O., BS, MS, PhD, U.S.A.

Burg, R., MD, Austria

Chandra, T. K., MBBS, India

Chauman, S. S., MBBS, TDD, India

Coosemans, M. H., MSc, Belgium

Cummins, B., BA, Britain

Deb, B. C., MBBS, MPH \& TM, India

Doherty, J. D. H., LRCP\&SI, DCH, DObst., DTM\&H, Italy

Dutta, R. N., MBBS, DTM\&H, India

East, Janet Sara, BSc, MSc, Britain

Everard, C. O. R., BSc, PhD, West Indies

Fleming, Brenda, $\mathrm{MB}$, ChB, Britain

Gabaudan, M., MD, Britain

Gardener, P. J., BSc, MSc, PhD, Kenya

Gear, J. S. S., BSc, MBBCh, DPH\&DTM\&H, FCPSA, DPhil, South Africa

Ghose, A. C., MSc, PhD, India

Giaconi, J. J., MD, South America

Ginger, C. D., BSc, MSc, PhD, MI Biol, Britain

Guevara, G. R. R., MD, MSc, Britain

Gwani, I. D., LMS, DPH, Britain
Hoffmann, G., MBChB, MFGP, DTM\&H, South Africa

Huq, M. M., MB, BS, India

Jepsen, S., MD, Denmark

Jeyraj, S. D., MD, MBBS, FCCP, FICA, FRSH, India

Keung, C. W., MB, BS, Hong Kong

Knight, A., BA, DPhil, Britain

Le Ray, D., DSc, Belgium

Macleod, C., MB, BS, FRCPA, Britain

Mallick, S., MBBS, India

Mohajery, M., DVM, Iran

Morgan, P. R. F., MBE, MB, BS, MRCS, LRCP, Britain

Namihira, Delia, BSc, MSc, Mexico

Oka, M., MAgr, Japan

Oketch, L. M., BSc, MSc, Nairobi

Olwit, G. W., MB, ChB, Uganda

Owen, R. L., MD, FACP, U.S.A.

Pal, S. C., MBBS, Dip Bact, $M D$, India

Parenti, D. M., MD, U.S.A.

Royaltey, H. H., MD, MPH, U.S.A.

Ruebush, T. K. (II), MD, U.S.A.

Saebi, E. S. E., MD, MPH, Iran

Siddig, A. M., MD, MB, BS, Britain

Smith, Judith E., BSc, DipNut, Britain

Soheranda, K. S., MD, Kenya

Tricot, J. P., MD, Belgium

Walker, G. J. A., MB, BS, MSc, MFCM, DCH, DRCOG, Britain

Weber, A. R., MD, U.S.A.

Weiss, M. G., PhD, MA, BA, U.S.A.

Whitaker, D. A., MB, BCh, DTM\&H, South Africa 